\title{
Implications of Helicobacter pylori infection for stomach cancer prevention
}

\author{
Implicações da infecção por Helicobacter pylori \\ na prevenção do câncer de estômago
}

Karen J. Goodman

School of Public Health, University of Texas Health Science Center. P. O. Box 20816, Houston, TX 77225, USA.
Abstract Accumulating evidence has implicated Helicobacter pylori, an established cause of chronic gastritis and peptic ulcer, in the etiol ogy of gastric cancer. Control of this infection would reduce the occurrence of chronic gastritis and peptic ulcer and might substantially lower the risk of stomach cancer as well. The public health impact of this infectious agent warrants efforts to identify preventive measures. This paper reviews the evidence linking $\mathrm{H}$. pylori infection to gastric cancer and evaluates the potential for control in high-risk populations. Current obstacles to $\mathrm{H}$. pylori control are discussed, including the link to poor socioeconomic conditions, difficulty in identifying incident cases, lack of natural immunity to reinfection, limited effectiveness of antibi otic therapy in high-prevalence populations, and incomplete knowl edge regarding the reservoir of infection, mode of transmission, host susceptibility factors, and the potential for developing an effective vaccine. Worth while avenues of research include studies desi gned to identify modifiable risk factors for acquisition of the infection, modifiable host factors that may increase resistance to chronic infection, more effective anti bi otic therapies, and effecti ve vaccines. Key words Helicobacter pylori; Prevention; Stomach; Cancer; Epidemiology

Resumo Um acúmulo de evidências aponta para Helicobacter pylori, uma causa comprovada de gastrite e úlcera péptica, na eti ol ogia do câncer gástrico. O controle dessa infecção poderia reduzir a ocorrência de gastrite crônica eúlcera péptica, além de diminuir o risco de câncer de estômago. O impacto desse agente infeccioso em nível de saúde pública justifica os esforços no sentido de identi ficar medidas preventi vas. Este artigo revê as evidências ligando o H. pylori ao câncer de estômago eavalia o potencial para controle em populações de alto risco. A autora discute os obstáculos atuais ao controle do $\mathrm{H}$. pylori, inclusi ve sua associação com condi ções suir o risco de câncer de estômago. O impacto desse agente infecciodentes, a falta de imunidade natural à reinfecção, a eficácia li mi tada da antibioticoterapia em populações com alta prevalência e o conhecimento incompleto sobre o reservatão com condi ções suir o risco de câncer de estômago. 0 impacto desse agente infecci opedei ro e possi bilidade de desenvolver uma vacina eficaz. Linhas de pesquisa prioritárias incluem estudos projetados para identificar fatores de risco modifi cávei s para a aqui si ção da infecção, fatores modificáveis no hospedei ro que possam aumentar a resistência à infecção, anti bi oti coterapias e vacinas mais eficazes.

Palavras-chave Helicobacter pylori; Prevenção; Câncer; Estômago; Epidemiologia 
Accumulating evidence has implicated Helicobacter pylori, now an established cause of chronic gastritis and peptic ulcer (Marshall, 1986; Korman \& Tytgat, 1995), in the etiology of gastric cancer (Forman, 1995; Parsonnet, 1993; Parsonnet et al., 1994). Successful control of this chronic infection would reduce the occurrence of gastritis and peptic ulcer and might substantially lower the risk of one of the world's deadliest neoplasms. The public health impact of this infectious agent justifies efforts to identify and implement preventive measures. Currently, however, limited knowledge regarding the natural history of $\mathrm{H}$. pylori infection in asymptomatic carriers, susceptibility factors, and the precise mode of transmission present obstacles to prevention (Goodman \& Correa, 1995). Furthermore, it is unclear how to treat this infection in patients from populations of low socioeconomic status who are most at risk of gastric cancer; eradication trials conducted in such populations have encountered limited success, and the risk of reinfection appears high. This paper reviews the evidence linking $\mathrm{H}$. pylori infection to cancer of the stomach and evaluates the potential for control in highrisk populations.

\section{Background}

$H$. pylori is a helical or curved bacillus that colonizes the gastric mucosa. It transforms to a nonculturable coccoid form under adverse environmental conditions, notably in the presence of antibiotics (Bode et al., 1992). Detection of $\mathrm{H}$. pylori has been problematic; special microbiological techniques are required for successful growth from gastric biopsy specimens (Goodwin \& Worsley, 1993). Attempts to isolate $\mathrm{H}$. pylori from bodily secretions or environmental sources have been unsuccessful in general. This problematic detection has presented obstacles to pinpointing portals of entry and exit as well as implicating or ruling out environmental reservoirs. Innovations in laboratory procedures have been gradually improving the sensitivity of detection techniques.

Serology has been the most extensively used diagnostic procedure for examining the distribution of $\mathrm{H}$. pylori infection in humans. The presence of $\mathrm{H}$. pylori antibodies indicates current infection with reasonable accuracy, except in individuals recently cleared of the infection, due to the persistence of elevated antibody levels for some months after clearance (Kosunen et al., 1992; Veenendaal et al., 1991). Infants born to $\mathrm{H}$. pylori-infected mothers ap- pear to have passively acquired $\mathrm{H}$. pylori IgG antibodies that disappear within the first months of life (Blecker et al., 1994). The urea breath test, a noninvasive procedure based on $\mathrm{H}$. pylori urease activity, has been developed in two versions, using either 13C-labeled (Graham et al., 1987; Graham \& Klein, 1991) or 14Clabeled (Marshall \& Surveyor, 1988; Surveyor et al., 1989) urea as an alternative to serology; the breath tests detect active infection exclusively and can be used for short-term follow-up of anti-H. pylori therapy. In validation studies the urea breath tests yield an accuracy that is comparable to the gold standard biopsy-based microbiological and histological diagnoses (Vandenplas et al., 1992; Logan et al., 1991; Dill et al., 1990; Raju et al., 1994; Marshall et al., 1991; Veldhuyzen van Zanten et al., 1990). Little validation of the urea breath tests has been conducted in Latin American populations; Coelho and colleagues (1990) reported a sensitivity of 97 percent and a specificity of 100 percent for the 14C-urea breath test validated against culture in 41 gastroscopy patients in Brazil. The radioactive exposure of the $14 \mathrm{C}$-urea breath test, although minimal, makes this test inappropriate for studies involving children, pregnant women, or follow-up screening at frequent intervals, whereas the higher cost of the 13Curea breath test limits its usefulness in population-based research. Serum pepsinogens have been proposed as markers of response to antiH. pylori therapy (Hunter et al., 1993).

The prevalence of $\mathrm{H}$. pylori infection ranges from $20 \%$ to over $90 \%$ in adult populations around the world (Pounder $\& \mathrm{Ng}, 1995)$. The prevalence is highest in developing regions, including the countries of Latin America (Table 1). A birth cohort effect noted in several developed countries, where the prevalence is relatively low in children and young adults but commonly exceeds $50 \%$ in adults over 50 years of age (Pounder \& Ng, 1995), has prompted speculation that transmission has decreased as sanitation has improved (Banatvala et al., 1993; Asaka et al., 1992; Gasbarrini et al., 1994). Within countries, H. pylori infection is linked to low socioeconomic status, residential overcrowding and migration from high prevalence regions (Eurogast Study Group, 1993; Smoak et al., 1994; Blecker \& Vanden plas, 1993; Malaty et al., 1992; Sitas et al., 1991; Graham et al., 1991; Fiedorek et al., 1991).

Several lines of evidence suggest that individuals become infected with $\mathrm{H}$. pylori primarily during childhood (Goodman \& Correa, 1995). It is commonly believed that the infection persists indefinitely, spontaneous elimination oc- 
Prevalence of Helicobacter pylori in Latin American populations.

\begin{tabular}{|c|c|c|c|c|}
\hline Population (Reference) & & Age & $\mathrm{n}$ & $\% \mathrm{HP}+*$ \\
\hline \multicolumn{5}{|l|}{ BRAZIL } \\
\hline Belo Horizonte & abattoir workers & $18-64$ & 160 & 66 \\
\hline (Rocha et al., 1992) & blood donors & $18-64$ & 160 & 62 \\
\hline \multirow[t]{3}{*}{ (O liveira et al., 1994) } & low SES, † laboratory outpatientsł & $3-8$ & 104 & 34 \\
\hline & & $9-14$ & 64 & 47 \\
\hline & & $15-18$ & 14 & 64 \\
\hline \multicolumn{5}{|l|}{ CHILE** } \\
\hline Santiago \& Punta Arenas & high SES, household cluster sample & $5-9$ & 216 & 30 \\
\hline \multirow[t]{7}{*}{ (Hopkins et al., 1993) } & & $10-14$ & 86 & 35 \\
\hline & & $15-19$ & 69 & 58 \\
\hline & & $20-34$ & 295 & 62 \\
\hline & Iow SES, household cluster sample & $5-9$ & 118 & 45 \\
\hline & & $10-14$ & 69 & 55 \\
\hline & & $15-19$ & 57 & 62 \\
\hline & & $20-34$ & 121 & 69 \\
\hline Iquique & middle class vaccine trial volunteers & $1-5$ & 229 & 23 \\
\hline \multirow[t]{2}{*}{ (Russell et al., 1993) } & & $6-8$ & 47 & 45 \\
\hline & & $10-16$ & 112 & 70 \\
\hline \multicolumn{5}{|c|}{ COLOMBIA, ANDEAN REGION†† } \\
\hline Aldana & rural, low SES census sample & $2-9$ & 685 & 69 \\
\hline \multicolumn{5}{|l|}{ (Goodman et al., in press) } \\
\hline Ipialesł $\ddagger$ & health professionals' children & $2-9$ & 57 & 54 \\
\hline \multicolumn{5}{|l|}{ COSTA RICA } \\
\hline Turrubares \& Hojancha & rural low SES schools, census sample & $7-10$ & 97 & 60 \\
\hline \multirow[t]{2}{*}{ (Sierra et al., 1992) } & & $11-13$ & 106 & 73 \\
\hline & & $14-20$ & 76 & 75 \\
\hline \multicolumn{5}{|l|}{ EL SALVADOR } \\
\hline refugees in Australia & routine entry examinations & $20-59$ & 63 & 41 \\
\hline (Dwyer et al., 1988) & & & & \\
\hline \multicolumn{5}{|l|}{ PERU } \\
\hline Limat† & high SES community volunteers & $2-12$ & 141 & 32 \\
\hline (Klein et al., 1991) & low SES health post patients & $2-12$ & 266 & 56 \\
\hline
\end{tabular}

* H. pylori prevalence, determined by serology except as noted

$\dagger$ socioeconomic status

$\ddagger$ excludes immunocompromised patients or those having taken antimicrobial drugs in the three preceding months

** prevalence approximated from graph

$\dagger \dagger \mathrm{H}$. pylori status determined by $13 \mathrm{C}$-urea breath test

$\ddagger \ddagger$ city on the Colombia-Ecuador border, author's unpublished data

curring rarely. However, this impression is based primarily on follow-up of prevalent cases, that is, cases with unknown time of onset. Followup of newly occurring cases has been extremeIy limited (Parsonnet, 1995); therefore, the proportion of acute infections that become chronic is not known. Recent longitudinal observation of Peruvian infants suggests that spontaneous elimination of $\mathrm{H}$. pylori infection may not be uncommon in young children (Klein et al., 1994).

\section{Helicobacter pylori and gastric cancer}

According to Correa's (1995) model of gastric carcinogenesis, continuous exposure to irritants of the gastric mucosa produces repeated episodes of superficial gastritis; when this occurs in concert with specific nutritional deficits, a degenerative sequential process yields atrophic gastritis, intestinal metaplasia, dysplasia and, ultimately, carcinoma. Although the 
precise role of $\mathrm{H}$. pylori in this sequence is not understood, the organism fits into the model as an irritant that causes chronic inflammation of the gastric mucosa (Correa, 1991).

Correa's model of gastric carcinogenesis evolved largely from longitudinal observations of a community-based cohort recruited between 1973 and 1983 from three small towns in the Andean region of Nariño in southern Colombia (Correa et al., 1990b, a). In previous studies, natives of this region displayed the highest stomach cancer rates in Colombia (Correa et al., 1970). The Nariño cohort revealed an extremely high prevalence of chronic gastritis and more advanced degenerative lesions as well as a high incidence of progression of these lesions and of gastric carcinoma itself. The prevalence of $\mathrm{H}$. pylori infection in a random sample of this cohort was over 90 percent (Correa et al., 1989).

While the evidence establishing $\mathrm{H}$. pylori as a cause of chronic gastritis accumulated, investigators began to study the occurrence of this infection in association with cancer of the stomach. Ecological studies contrasting regions of high and low gastric cancer risk conducted in Colombia and China revealed correlations between gastric cancer rates and $H$. pylori seroprevalence, as did a 13-country comparison (IARC, 1994). Similar studies conducted in Costa Rica, Italy, and Japan did not reveal such associations, the observed range of $H$. pylori seroprevalence being quite narrow in each of these countries (IARC, 1994). The observation of distinct gastric cancer rates in populations of similar $\mathrm{H}$. pylori prevalence does not constitute evidence against a role for $\mathrm{H}$. pylori in the etiology of cancer of the stomach, but rather, suggests that $H$. pylori itself is not a sufficient cause of this cancer; the contrasting gastric cancer rates in these populations could reflect different distributions of cofactors that interact with $\mathrm{H}$. pylori in the carcinogenic process.

Case-control studies conducted in nine countries comparing $\mathrm{H}$. pylori seroprevalence status in gastric cancer patients to controls matched on age and sex, show inconsistencies but overall suggest a positive association (IARC, 1994). It has been argued that this design results in an underestimate of the relative risk, however, because $\mathrm{H}$. pylori colonization tends to diminish with increasing degeneration of the gastric mucosa and antibodies titers decline following clearance of the infection (Forman, 1995). Gastric cancer cases would have increasingly less normal mucosa relative to controls and would be more likely to lose their infection over time. To address this problem, nested case-control studies determining $\mathrm{H}$. pylori status from stored sera collected prior to cancer diagnosis were conducted in England and Wales (odds ratio $(O R)=2.8,95 \%$ confidence interval $(\mathrm{Cl})=1.0-8.0$ ) (Forman et al., 1991), California (OR=3.6, $\mathrm{Cl}=1.8-7.3$ ) (Parsonnet et al., 1991), and Hawaii ( $\mathrm{OR}=6.0, \mathrm{Cl}=2.1$ 17.0) (Nomura et al., 1991). In order to assess the potential misclassification of infection status in cancer cases when the follow-up is brief, Forman and colleagues (1994) pooled the data from these three studies and stratified the observations by time interval between collection of serum and cancer diagnosis, observing a monotonic increase in the odds ratio ( 2.3 for 5 9 years; 4.4 for $10-14$ years; 8.7 for $>14$ years) as the follow-up interval lengthens.

Particularly strong and consistent evidence has linked $\mathrm{H}$. pylori infection to gastric lymphoma, a relatively rare form of stomach cancer. A high $\mathrm{H}$. pylori prevalence has been observed in cases of gastric lymphoma (Forman, 1995). A nested case-control study using two large cohorts in the U.S. and Norway matched 33 gastric lymphoma cases, primarily of the diffuse large-cell type, to each of four controls on cohort, date of birth, sex, and date and site of serum collection, observing a relative risk of $6.3(\mathrm{Cl}=2.0-19.9)$ for $\mathrm{H}$. pylori seropositivity and subsequent development of gastric nonHodgkin's lymphoma, while nongastric nonHodgkin's lymphoma did not appear related to previous $\mathrm{H}$. pylori infection (Parsonnet et al., 1994). The median interval between serum collection and cancer diagnosis was 14 years and the relative risk increased to $12.3(\mathrm{Cl}=1.5$ 103.9) among those whose serum had been collected 14 years or more prior to diagnosis. The strongest suggestion that $\mathrm{H}$. pylori causes gastric lymphoma comes from the follow-up of several series of $\mathrm{H}$. pylori-infected patients with primary low-grade gastric lymphoma of the mucosa-associated lymphoid tissue type after anti-H. pylori therapy; tumor regression occurred in most patients whose infection was successfully eradicated (Wotherspoon et al., 1993; Roggero et al., 1995; Bayerdorffer et al., 1995).

Based on the above evidence, a Working Group on the Evaluation of Carcinogenic Risks to Humans convened by the International Agency for Research on Cancer in June 1994 concluded that infection with Helicobacter pylori is carcinogenic to humans (IARC, 1994). It must be noted, however, that no published study to date has produced estimates of the effect of $\mathrm{H}$. pylori infection on the subsequent in- 
cidence of gastric cancer adjusted for known dietary risk factors including high intake of salt and nitrates and deficient intake of vitamin C and beta-carotene (Correa, 1991). There is reason to suspect that these dietary factors, being more common among populations of low socioeconomic status, may confound observed associations between $\mathrm{H}$. pylori infection and gastric cancer, given the clear link between the infection and low socioeconomic status.

\section{Perspectives for control}

Little progress has been made towards identifying preventive measures for $\mathrm{H}$. pylori infection, primarily due to obstacles presented by the natural history of this infection, its epidemiology, resistance to eradication, and limitations of our current state of knowledge.

\section{Obstacles to H. pylori Control}

- Natural history

$H$. pylori infection is frequently asymptomatic and when symptoms do occur these represent nonspecific forms of stomach discomfort (Rauws \& Tytgat, 1989); incident cases, therefore, are not generally detected at the time of onset. Given that antibody levels decline following clearance of infection (Kuipers et al., 1993), natural immunity does not appear to provide lasting protection against reinfection. Coinfection with multiple strains is not uncommon (Costas et al., 1991), suggesting the possibility of continual reinfection.

- Epidemiology

H. pylori occurs commonly throughout the world, implying a vast reservoir of infection. Given that the infection is linked to poor socioeconomic conditions, control may require broad socioeconomic changes.

\section{- Eradication of infection}

Due to the protection afforded to $\mathrm{H}$. pylori by its ecological niche under the mucus layer of the gastric mucosa, effective antibiotic treatment requires costly and burdensome multidrug regimens that have shown limited effectiveness in populations where the infection is most prevalent (Buiatti et al., 1994; Glupczynski \& Burette, 1990). Factors that may contribute to this reduced effectiveness include high bacterial loads in individuals from such populations due to continual exposure to the agent, the high prevalence of drug resistant strains, and lifestyle factors including deficient diet, limited education, economic constraints, and alcoholism that do not favor compliance and/ or drug tolerance. Furthermore, even when treatment is successful in high prevalence populations, the risk of reinfection appears high. Although few followup studies have been conducted in developing countries, Brazilian investigators observed the reinfection rate in the first year after standard triple therapy among 269 patients who had been successfully cleared of $\mathrm{H}$. pylori infection as confirmed by negative urea breath tests at a median time of 83 days following treatment (Coelho et al., 1995). The proportion of patients who became reinfected by approximately one year after treatment was 31 percent among 223 participants of low socioeconomic status in contrast to nine percent among 46 participants of high socioeconomic status. The reinfection rate among Brazilians of high socioeconomic status approximates rates observed in developed countries; reported reinfection rates following confirmed eradication in adults from the U.S., Australia, Finland, Austria, Belgium, France and the UK range from 0-5 percent per year (Parsonnet, 1995). Aside from socioeconomic status, another risk factor for reinfection detected in the Brazilian study was receiving endoscopy at the initial post-treatment followup visit. This finding is consistent with previous reports implicating gastroscopes disinfected by manual washing as potential vehicles of $\mathrm{H}$. pylori transmission (Goodman \& Correa, 1995).

\section{- Limitations in knowledge}

Currently it is not known if a reservoir exists outside of humans and the precise mode of transmission has not been identified. Modifiable risk factors for infection have not been clearly identified, with the exception of clinical procedures that transfer gastric secretions from one patient to another. Furthermore, vaccine research is at a preliminary stage. The knowledge required for proposing preventive measures, aside from precautions against iatrogenic transmission, is lacking.

\section{Current state of knowledge relevant}

to prevention

- Transmission of $\mathrm{H}$. Pylori

Table 2 summarizes the evidence supporting hypothesized modes of transmission, while Table 3 presents factors that have been associ- 
Table 2

Evidence for Helicobacter pylori transmission pathways*.

Person-to-person transmission

clustering in families and groups residences

association with residential crowding

childhood acquisition suggests transmission related to personal hygiene

isolation from human feces and dental plaque (though most attempts unsuccessful)

detection in human feces, saliva, and dental plaque by polymerase chain reaction

Waterborne transmission

survival in laboratory aquatic environments

detection by polymerase chain reaction in water samples from Colombiat and Peruł

association with drinking water source in Andean countries**

association with raw vegetable consumption in Andean countries**

association with swimming in rivers and swimming pools in Colombia**

Zoonotic transmission

successful experimental infection of monkeys, mice, cats, germ-free pigs, germ-free dogs

observation of natural infection in research monkeys and cats

observation of human infection by animal Helicobacter species

latrogenic transmission

outbreaks of acute gastritis among gastroscopy patients and research subjects exposed to gastric $\mathrm{pH}$ electrodes

detection of viable $\mathrm{H}$. pylori in manually disinfected gastrofiberscopes

* referenced in (Goodman \& Correa, 1995) except as noted

$\dagger$ (Schauer et al., 1995)

$\ddagger$ (Hulten et al., 1995)

** see also (Goodman et al., 1996) man \& Correa, 1995). H. pylori DNA has been detected in gastrointestinal equipment disinfected according to standard procedures (Katoh et al., 1993; Roosendaal et al., 1993). Viable $\mathrm{H}$. pylori was recovered by bacterial culture from $19 \%$ of wash-out samples from the gastrofiberscope biopsy-suction channel after manual Hyamine washing; however, no H. pylori was recovered after mechanical washing (Katoh et al., 1993). These observations along with the previously cited evidence that endoscopy may increase the risk of reinfection in patients undergoing anti-H. pylori therapy points to the urgency of adopting stringent precautions aimed at preventing infection in the clinical setting.

\section{- Cofactors for infection}

A small number of studies have attempted to identify cofactors linked to $\mathrm{H}$. pylori infection that are not indicators of specific transmission pathways, but may reflect host susceptibility. Very few studies have examined cofactors associated with the risk of acquiring infection. In a cohort of U.S. epidemiologists, frequent consumption of caffeinated beverages was linked to an increased risk of seroconversion, while frequent consumption of milk appeared protective (Parsonnet et al., 1992). In a follow-up study of Peruvian infants, males were more likely than females to become infected and to remain infected (Klein et al., 1994). Most studies linking potential cofactors to $\mathrm{H}$. pylori infection have been cross-sectional. For exposures that change over time, it may not be clear whether cross-sectionally identified covariates are causes or consequences of infection. Furthermore, if spontaneous elimination of $\mathrm{H}$. pylori occurs to an important degree, it cannot be determined whether such covariates influence the acquisition of the infection or its chronicity. Indicators of deficient nutritional status have been linked to increased $\mathrm{H}$. pylori prevalence in both developed and developing countries (Goodman et al., 1996; Klein et al., 1991; Raymond et al., 1994; Patel et al., 1994; Mendall et al., 1994; Eurogast Study Group, 1993), although the importance of specific indicators varies across studies. A study of 249 children, 0-18 years of age, sampled from an outpatient clinic serving patients of low socioeconomic status in Belo Horizonte, Brazil reported no statistically significant associations between $\mathrm{H}$. pylori serostatus and nutritional status (Oliveira et al., 1994), although it must be noted that the study sample was not 
Factors associated with Helicobacter pylori infection in Latin American populations.

\begin{tabular}{|c|c|c|}
\hline Population & Outcome measure & Associated factor \\
\hline \multicolumn{3}{|l|}{ BRAZIL, Belo Horizonte } \\
\hline $\begin{array}{l}249 \text { outpatients, } 0 \text { - } 18 \text { years old } \\
\text { (O liveira et al., 1994) }\end{array}$ & seroprevalence & age \\
\hline $\begin{array}{l}269 \text { duodenal ulcer patients after } \\
\text { successful anti-H. pylori therapy,* } \\
18 \text { - } 79 \text { years old } \\
\text { (Coelho et al., 1995) }\end{array}$ & $\begin{array}{l}\text { reinfection rate } \\
\text { by } 14 \text { C-UBT† }\end{array}$ & $\begin{array}{l}\text { low socioeconomic status } \\
\text { gastroscopy at the first postreatment visit }\end{array}$ \\
\hline $\begin{array}{l}\text { CHILE, Santiago \& Punta Arenas } ¥ \\
\text { 1,815 community members, household } \\
\text { cluster sample, } 0-34 \text { years old } \\
\text { (Hopkins et al., 1993) }\end{array}$ & seroprevalence & $\begin{array}{l}\text { age } \\
\text { male sex } \\
\text { low socioeconomic status } \\
\text { consumes uncooked vegetables } \\
\text { resides in Santiago v. Punta Arenas } \\
\text { consumes uncooked shellfish }\end{array}$ \\
\hline $\begin{array}{l}\text { CO LOMBIA, Aldanał } \\
684 \text { rural residents, census sample, } \\
2-9 \text { years old } \\
\text { (Goodman et al., 1996) }\end{array}$ & $\begin{array}{l}\text { prevalence } \\
\text { by } 13 \mathrm{C} \text {-UBT† }\end{array}$ & $\begin{array}{l}\text { age } \\
\text { male sex } \\
\text { more than } 1 \text { child resides in home } \\
\text { consumes }<2 \text { fruits/vegetable servings/day } \\
\text { consumes }<2 \text { cups of milk/day } \\
\text { low height/age } \\
\text { nonagricultural parental occupation } \\
\text { mother not gainfully employed } \\
\text { home has no toilet/latrine } \\
\text { drinking water obtained from river } \\
\text { swims in river/swimming pool } \\
\text { cares for or plays with sheep } \\
\text { recent history of amebiasis (protective) }\end{array}$ \\
\hline $\begin{array}{l}\text { CO LOMBIA, Ipiales (border city) } \neq \\
69 \text { children of health professionals } \\
\text { census sample, } 2-12 \text { years old } \\
\text { (author's unpublished data) }\end{array}$ & $\begin{array}{l}\text { prevalence } \\
\text { by } 13 \mathrm{C} \text {-UBT† }\end{array}$ & $\begin{array}{l}\text { age } \\
\text { infrequent consumption of fruits and vegetables } \\
\text { household has pet(s) (protective) } \\
\text { recent history of parasitic infection (protective) }\end{array}$ \\
\hline $\begin{array}{l}\text { PERU, peri-urban Lima } \\
56 \text { infants, } 6-30 \text { months old } \\
\text { (Klein et al., 1994) }\end{array}$ & $\begin{array}{l}\text { incidence } \\
\text { by } 13 \mathrm{C} \text {-UBT† }\end{array}$ & male sex \\
\hline PERU, Limał & & \\
\hline $\begin{array}{l}407 \text { community members, } 0-12 \text { years old } \\
\text { (Klein et al., 1991) }\end{array}$ & $\begin{array}{l}\text { prevalence } \\
\text { by } 13 C \text {-UBT† }\end{array}$ & $\begin{array}{l}\text { age } \\
\text { low socioeconomic status } \\
\text { municipal v. well drinking water source } \\
\text { external v. internal drinking water source } \\
\text { low height/age } \\
\text { low weight/height }\end{array}$ \\
\hline
\end{tabular}

* five day treatment with amoxicillin, furazolidone, and metronidazole followed by a negative 14C-urea breath test at a median of 83 days following treatment

$\dagger$ multivariate analysis including all factors listed

‡ urea breath test 
population-based and reflected a high degree of homogeneity on relevant exposures. In a large study conducted in Southern China, frequent use of antibiotics was linked to decreased H. pylori seroprevalence (Mitchell et al., 1992).

\section{- Vaccine prospects}

The mouse has been established as an animal model that can be infected with $\mathrm{H}$. pylori for the purpose of vaccine research; recently, oral immunization with purified $\mathrm{H}$. pylori antigens has been reported to protect mice against $\mathrm{H}$. pylori infection (Marchetti et al., 1995). Previous reports document successful protection against infection by Helicobacter felis in mice, using the following orally administered combinations: $\mathrm{H}$. felis antigen plus adjuvant cholera toxin as well as the nontoxic cholera toxin B subunit (Lee, A. \& Chen, 1994); recombinant H. pylori GroES-like heat shock proteins in combination with the $\mathrm{B}$ subunit of $\mathrm{H}$. pylori urease (Ferrero et al., 1995); and recombinant $\mathrm{H}$. pylori urease with adjuvant E. coli toxin (Lee, C. K. et al., 1995). Currently it is not known whether a similar protection against $\mathrm{H}$. pylori infection of adequate duration can be achieved in humans.

\section{References}

ASAKA, M.; KIMURA, T.; KUDO, M .; TAKEDA, H.; MITANI, S.; MIYAZAKI, T.; MIKI, K. \& GRAHAM, D. Y., 1992. Relationship of Helicobacter pylori to serum pepsinogens in an asymptomatic Japanese population. Gastroenterology, 102:760-766.

BANATVALA, N.; MAYO, K.; MEGRAUD, F.; JENNINGS, R.; DEEKS, J. J. \& FELDMAN, R. A., 1993. The cohort effect and Helicobacter pylori. Journal of Infectious Diseases, 168:219-221.

BAYERDORFFER, E.; NEUBAUER, A.; RUDOLPH, B.; THIEDE, C.; LEHN, N.; EIDT, S. \& STOLTE, M., 1995. Regression of primary gastric lymphoma of mucosa-associated lymphoid tissue type after cure of Helicobacter pylori infection. Lancet, 346:448-449.

BLECKER, U. \& VANDENPLAS, Y., 1993. Ethnic differences in Helicobacter pylori infection. European Journal of Pediatrics, 152:377-380.

\section{Conclusions}

Current obstacles to the control of $\mathrm{H}$. pylori infection include its widespread distribution linked to poor socioeconomic conditions, difficulty in identifying incident cases, lack of natural immunity to reinfection, limited effectiveness of antibiotic therapy in populations where transmission is most frequent, difficulty in detecting the organism outside the stomach, and incomplete knowledge regarding the reservoir of infection, mode of transmission, host susceptibility factors and the potential for developing a successful vaccine. These obstacles not only represent a challenge to those concerned with prevention of the infection itself, they also impede research designed to observe the potential for anti-H. pylori therapy to prevent the progression of precancerous lesions of the stomach. Worthwhile avenues of research include studies designed to identify risk factors for acquisition of the infection that may be modified in order to interrupt transmission, modifiable host factors that may make individuals resistant to chronic infection, antibiotic therapies that are effective in high prevalence populations of low socioeconomic status and effective vaccines.
BLECKER, U.; LANCIERS, S.; KEPPENS, E. \& VANDENPLAS, Y.; 1994. Evolution of Helicobacter pylori positivity in infants born from positive mothers. Journal of Pediatric Gastroenterology and Nutrition, 19:87-90.

BODE, G.; MALFERTHEINER, P.; STROHLE, A.; MAUCH, F.; NILIUS, M. \& DITSCHUNEIT, H., 1992. Polymorphism in Helicobacter pylori - a key function in recurrence of infection? Medizinische Klinik, 87:179-184.

BUIATTI, E.; MUÑOZ, N.; VIVAS, J.; CANO, E.; PERAZA, S.; CARILLO, E.; CASTRO, D.; SANCHEZ, V.; ANDRADE, O.; BENZ, M.; DE SANJOSÉ, S. \& OLIVER, W., 1994. Difficulty in eradicating Helicobacter pylori in a population at high risk for stomach cancer in Venezuela. Cancer Causes and Control, 5:249-254. 
COELHO, L. G.; CHAUSSEN, Y.; PASSOS, M. C.; SADALA, R. U.; COSTA, E. L.; SABINO, C. V.; QUEIROZ, D. M.; MENDES, E. N.; ROCHA, G. A. \& OLIVEIRA, C. A., 1990. 14C-urea breath test to diagnose gastric Helicobacter pylori colonization. Gastroenterologie Clinique et Biologique, 14:801805.

COELHO, L. G. V.; PASSOS, M. C. F.; CHAUSSON, Y.; CASTRO, F. J.; VIEIRA, W. L. S.; FRANCO, J. M. M.; MORETZSOHN, L. D.; ANDRADE, A. M.; GUEDES, L. M.; MIRANDA, S. C.; MACIEL, C. D.; FERNANDES, M. L. M.; YAZAKI, F. R.; SOUZA, E. M. M. \& CASTRO, L. P., 1995. Factors involved in reinfection by H. pylori in Brazil. Gut, 37:71.

CORREA, P., 1991. The epidemiology of gastric cancer. World Journal of Surgery, 15:228-234.

CORREA, P., 1995. Helicobacter pylori and gastric carcinogenesis. American Journal of Surgical Pathology, 19:S37-S43.

CORREA, P.; CUELLO, C. \& DU QUE, E., 1970. Carcinoma and intestinal metaplasia of the stomach in Colombian migrants. Journal of the National Cancer Institute, 44:297-306.

CORREA, P.; MUÑOZ, N.; CUELLO, C.; FOX, J.; ZAVALA, D. \& RUIZ, B., 1989. The role of Campylobacter pylori in gastro-duodenal disease. In: Progress in Surgical Pathology (C. Fenoglio-Preiser, ed.), pp. 191-210, Philadel phia: Field \& Wood.

CORREA, P.; HAENSZEL, W.; CUELLO, C.; ZAVALA, D.; FONTHAM, E.; ZARAMA, G.; TANNENBAUM, S.; COLLAZOS, T. \& RUIZ, B., 1990a. Gastric precancerous process in a high risk population: cohort followup. Cancer Research, 50:4737-4740.

CORREA, P.; HAENSZEL, W.; CUELLO, C.; ZAVALA, D.; FONTHAM, E.; ZARAMA, G.; TANNENBAUM, S.; COLLAZOS, T. \& RUIZ, B., 1990b. Gastric precancerous process in a high risk population: crosssectional studies. Cancer Research, 50:4731-4736.

COSTAS, M.; OWEN, R. J.; BICKLEY, J. \& MORGAN, D. R., 1991. Molecular techniques for studying the epidemiology of infection by Helicobacter pylori. Scandinavian Journal of Gastroenterology, 26:2032.

DILL, S.; PAYNE-JAMES, J. J.; MISIEWICZ, J. J.; GRIMBLE, G. K.; MCSWIGGAN, D.; PATHAK, K.; WOOD, A. J.; SCRI M GEOUR, C. M. \& RENNIE, M. J., 1990. Evaluation of the 13C-urea breath test in the detection of $\mathrm{H}$. pylori and in monitoring the effect of tripotassium dicitratobismuthate in nonculser dyspepsia. Gut, 31:1237-1241.

DWYER, B.; KALDOR, J.; TEE, W.; MARAKOWSKI, E. \& RAIOS, K., 1988. Antibody response to campylobacter pylori in diverse ethnic groups. Scandinavian Journal of Infectious Disease, 20:349-350.

EUROGAST STUDY GROUP, 1993. Epidemiology of, and risk factors for, Helicobacter pylori infection among 3194 asymptomatic subjects in 17 populations. Gut, 34:1672-1676.

FERRERO, R. L.; THIBERGE, J. M.; KANSAU, I.; WUSCHER, N.; HUERRE, M. \& LABIGNE, A., 1995. The GroES homolog of Hel i cobacter pylori confers protective immunity against mucosal infection in mice. Proceedings of the National Academy of Sciences of the United States of America, 92:6499-6503.
FIEDOREK, S. C.; MALATY, H. M.; EVANS, D. L.; PUMPHREY, C. L.; CASTEEL, H. B.; EVANS, D. J. \& GRAHAM, D. Y., 1991. Factors influencing the epidemiology of Helicobacter pylori infection in children. Pediatrics, 88:578-582.

FORM AN, D., 1995. The prevalence of Helicobacter pylori infection in gastric cancer. Alimentary Pharmacology \& Therapeutics, 9:71-76.

FORMAN, D.; NEWELL, D. G.; FULLERTON, F.; YARNELL, J. W. G.; STACEY, A. R.; WALD, N. \& SITAS, F., 1991. Association between infection with Helicobacter pylori and risk of gastric cancer: evidence from a prospective investigation. British Medical Journal, 302:1302-1305.

FORM AN, D.; WEBB, P. \& PARSONNET, J., 1994. H. pylori and gastric cancer. Lancet, 343:243-244.

GASBARRINI, G.; PRETOLANI, S.; GHIRONZI, G. C.; GIULIANELLI, G.; TONELLI, E.; GATTO, M. R. A.; FERRARI, S.; MEGRAUD, F.; BARALDINI, M.; CILLA, D.; BALDINELLI, S.; BAZZOCCHI, E. \& BONVICINI, F., 1994. The Helicobacter pylori-San Marino study: seroepidemiology of Helicobacter pylori infection in the Republic of San Marino. In: Basic and Clinical Aspects of Heli cobacter pylori Infection (G. Gasbarrini \& S. Pretolani, eds.), pp. 168-176. Berlin: Springer-Verlag.

GLUPCZYNSKI, Y. \& BURETTE, A., 1990. Drug therapy for Heli cobacter pylori infection: problems and pitfalls. American Journal of Gastroenterology, 85:1545-1551.

GOODM AN, K. J. \& CORREA, P., 1995. The transmission of Helicobacter pylori. A critical review of the evidence. International Journal of Epidemiology, 24:875-887.

GOODMAN, K. J.; CORREA, P.; TENGANÁ-AUX, H. J.; RAMÍREZ, H.; DELANY, J. P.; GUERRERO-PEPINOSA, O.; LÓPEZ-QUIÑONES, M. \& COLLAZOS-PARRA, T., 1996. Helicobacter pylori infection in the Colombian Andes: a population-based study of transmission pathways. American Journal of Epidemiology, 144:290-9.

GOODWIN, C. S. \& WORSLEY, B. W., 1993. Microbiology of Helicobacter pylori. Gastroenterol ogy Clinics of North America, 22:5-20.

GRAHAM, D. Y. \& KLEIN, P. D., 1991. What you should know about the methods, problems, interpretations, and uses of urea breath tests. American Journal of Gastroenterology, 86:1118-1121.

GRAHAM, D. Y.; KLEIN, P. D.; EVANS, D. J.; EVANS, D. G.; ALPERT, L. C.; OPEKUN, A. R. \& BOUTTON, T. W., 1987. Campylobacter pylori detected noninvasively by the $13 \mathrm{C}$-urea breath test. Lancet, 1:1174-1177.

GRAHAM, D. Y.; MALATY, H. M.; EVANS, D. G.; EVANS, D. J.; KLEIN, P. D. \& ADAM, E., 1991. Epidemiology of Helicobacter pylori in an asymptomatic population in the United States. Gastroenterology, 100:1495-1501.

HOPKINS, R. J.; VIAL, P. A.; FERRECCIO, C.; OVALLE, J.; PRADO, P.; SOTOM AYOR, V.; RUSSELL, R. G.; WASSERMAN, S. S. \& MORRIS, J. G. J., 1993. Seroprevalence of Helicobacter pylori in Chile: vegetables may serve as one route of transmission. Journal of Infectious Diseases, 168:222-226. 
HULTEN, K.; HAN, S. W.; EL-ZAATARI, F. A. K.; EVANS, D. G.; KLEIN, P. D.; OPEKUN, A. R.; GILMAN, R. H.; GRAHAM, D. Y. \& ENGSTRAND, L., 1995. Detection of Helicobacter pylori in Peruvian water sources by two PCR assays based on independent genes. Gut, 37:10.

HUNTER, F. M.; CORREA, P.; FONTHAM, E.; RUIZ, B.; SOBHAN, M. \& SAMLOFF, M., 1993. Serum pepsinogens as markers of response to therapy for Helicobacter pylori gastritis. Digestive Diseases and Sciences, 38:2081-2086.

IARC (International Agency for Research on Cancer), 1994. Schistosomes, liver flukes and Helicobacter pylori. Lyon: IARC Monographs on the Evaluation of Carginogenic Risks to Humans. v. 61.

KATOH, M.; SAITO, D.; NODA, T.; YOSHIDA, S.; OGURU, Y.; YAZAKI, Y.; SU GIMURA, T. \& TERADA, M., 1993. Helicobacter pylori may be transmitted through gastrofiberscope even after manual Hyamine washing. Japanese Journal of Cancer Research, 84:117-119.

KLEIN, P. D.; Gastrointestinal Physiology Working Group; GRAHAM, D. Y., 1991. Water source as a risk factor for Helicobacter pylori infection in Peruvian children. Lancet, 337:1503-1506.

KLEIN, P. D.; GILMAN, R. H.; LEON-BARUA, R.; DIAZ, F.; O'BRIAN-SMITH, E. \& GRAHAM, D. Y., 1994. The epidemiology of Helicobacter pylori in Peruvian children between 6 and 30 months of age. American Journal of Gastroenterology, 89:21962199.

KORMAN, M. G. \&TYTGAT, G. N., 1995. Helicobacter pylori and peptic ulcer. Scandinavian Journal of Gastroenterology, 210:92-96.

KOSUNEN, T. U.; SEPPALA, K.; SARNA, S. \& SIPPONEN, P., 1992. Diagnostic value of decreasing IgG, IgA, and IgM antibody titres after eradication of Helicobacter pylori. Lancet, 339:893-895.

KUIPERS, E. J.; PEÑA, A. S.; VAN KAMP, G.; UYTERLINDE, A. M.; PELS, N. F. M.; KURZ-POHLMANN, E. \& MEUWISSEN, S. G. M., 1993. Seroconversion for Helicobacter pylori. Lancet, 342:328-331.

LEE, A. \& CHEN, M., 1994. Successful immunization against gastric infection with B-subunit-wholecell vaccine. Infection and Immunity, 62:35943597.

LEE, C. K.; WELTZIN, R.; THOMAS, W. D.; KLEANTHOUS, H.; ERMAK, T. H.; SOMAN, G.; HILL, J. E.; ACKERMAN, S. K. \& MONATH, T. P., 1995. Oral immunization with recombinant Helicobacter pylori urease induces secretory IgA antibodies and protects mice from challenge with Helicobacter felis. Journal of Infectious Diseases, 172:161-172.

LOGAN, R.; POLSON, R.; MISIEWICZ, J.; RAO, G.; KARIM, N.; NEWELL, D.; JOHNSON, P.; WADSWORTH, J.; WALKER, M. \& BARON, J., 1991. Simplified single sample 13 Carbon urea breath test for Helicobacter pylori: comparison with histology, culture, and ELISA serology. Gut, 32:14611464.

MALATY, H. M.; EVANS, D. G.; EVANS, D. J. \& GRAHAM, D. Y.; 1992. Helicobacter pylori in Hispanics: comparison with blacks and whites of similar age and socioeconomic class. Gastroenterology, 103:813-816.
MARCHETTI, M.; ARICO, B.; BURRONI, D.; FIGURA, N.; RAPPOULI, R. \& GHIARA, P., 1995. Development of a mouse model of Helicobacter pylori infection that mimics human disease. Science, 267:1655-1658.

MARSHALL, B. J., 1986. Campyl obacter pyloridis and gastritis. Journal of Infectious Diseases, 153:650657.

M ARSHALL, B. J. \& SURVEYOR, I., 1988. Carbon-14 urea breath test for the diagnosis of Campylobacter pylori associated gastritis. Journal of Nuclear Medicine, 29:11-16.

MARSHALL, B. J.; PLANKEY, M. W.; HOFFMAN, S. R.; BOYD, C. L.; DYE, K. R.; FRIERSON, H. F. J.; GUERRANT, R. L. \& MCCALLUM, R. W., 1991. A 20-minute breath test for $\mathrm{H}$. pylori. American Journal of Gastroenterology, 86:438-445.

MENDALL, M. A.; MOLINEAUX, N.; LEVI, J.; STRACHAN, D. \& NORTHFIELD, T. C., 1994. Association of $\mathrm{H}$. pylori with diminished adult height. Gastroenterology, 106:137.

MITCHELL, H. M.; LI, Y. Y.; HU, P. J.; LIU, Q.; CHEN, M.; DU, G. G.; WANG, Z. J.; LEE, A. \& HAZELL, S. L., 1992. Epidemiology of Helicobacter pylori in Southern China: identification of early childhood as the critical period for acquisition. Journal of Infectious Diseases, 166: 149-153.

NOMURA, A.; STEM MERMANN, G. N.; CHYOU, P. H.; KATO, I.; PEREZ-PEREZ, G. I. \& BLASER, M. J.; 1991. Helicobacter pylori infection and gastric carcinoma among Japanese Americans in Hawaii. New England Journal of Medicine, 325:1132-1136.

OLIVEIRA, A. M. R.; QUEIROZ, D. M. M.; ROCHA, G. A. \& MENDES, E. N., 1994. Seroprevalence of Hel i cobacter pylori infection in children of low socioeconomic level in Belo Horizonte, Brazil. American Journal of Gastroenterology, 89:22012204.

PARSONNET, J., 1993. Helicobacter pylori and gastric cancer. Gastroenterology Clinics of North America, 22:89-104.

PARSONNET, J., 1995. The incidence of Helicobacter pylori infection. Alimentary Pharmacology \& Therapeutics, 9:45-52.

PARSONNET, J.; FRIEDMAN, G. D.; VANDERSTEEN, D. P.; CHANG, Y.; VOGELMAN, J. H.; ORENTREICH, N. \& SIBLEY, R. K., 1991. Helicobacter pylori infection and the risk of gastric carcinoma. New England Journal of Medicine, 325:1127-1131.

PARSONNET, J.; BLASER, M. J.; PEREZ-PEREZ, G. I.; HARGRETT-BEAN, N. \&TAUXE, R. V., 1992. Symptoms and risk factors of Helicobacter pylori infection in a cohort of epidemiologists. Gastroenterology, 102:41-46.

PARSONNET, J.; HANSEN, S.; RODRIGUEZ, L.; GELB, A. B.; WARNKE, R. A.; JELLUM, E.; ORENTREICH, N.; VOGELM AN, J. H. \& FRIEDM AN, G. D., 1994. Helicobacter pylori infection and gastric lymphoma. New England Journal of Medicine, 330:1267-1271.

PATEL, P.; MENDALL, M. A.; KHULUSI, S.; NORTHFIELD, T. C. \& STRACHAN, D. P., 1994. Helicobacter pylori infection in childhood: risk factors and effect on growth. British Medical Journal, 309 : 1119-1123. 
POUNDER, R. E. \& NG, D., 1995. The prevalence of Helicobacter pylori infection in different countries. Alimentary Pharmacology \& Therapeutics, 9:33-40.

RAJU, G. S.; SMITH, M. J.; MORTON, D. \& BARDHAN, K. D.; 1994. Mini-dose (1-microCi) 14Curea breath test for the detection of Helicobacter pylori. American Journal of Gastroenterology, 89: 1027-1031.

RAUWS, E. A. J. \& TYTGAT, G. N. J., 1989. Natural history of C. Pylori infection. In: Campylobacter pyIori in Gastritis and Peptic Ulcer Disease (M. J. Blaser, ed.), pp. 187-194. New York: Igaku-Shoin.

RAYMOND, J.; BERGERET, M.; BENHAMOU, P. H.; MENSAH, K. \& DUPONT, C., 1994. A 2-year study of Helicobacter pylori in children. Journal of Clinical Microbiology, 32:461-463.

ROCHA, G. A.; QUEIROZ, D. M.; MENDES, E. N.; OLIVEIRA, A. M.; MOURA, S. B. \& SILVA, R. J., 1992. Source of Helicobacter pylori infection: studies in abattoir workers and pigs. American Journal of Gastroenterology, 87:1525.

ROGGERO, E.; ZUCCA, E.; PINOTTI, G.; PASCARELLA, A.; CAPELLA, C.; SAVIO, A.; PEDRINIS, E.; PATERLINI, A.; VENCO, A. \& CAVALLI, F., 1995. Eradication of Helicobacter pylori infection in primary low-grade gastric lymphoma of mucosa-associated lymphoid tissue. Annals of Internal Medicine, 122:767-769.

ROOSENDAAL, R.; KUIPERS, E. J.; VAN DEN BRULE, A. J.; PENA, A. J.; MEUWISSEN, S. G.; WALBOOMERS, J. M. \& DE GRAAFF, J., 1993. Detection of Helicobacter pylori DNA by PCR in gastrointestinal equipment. Lancet, 341:900.

RUSSELL, R. G.; WASSERMAN, S. S.; O'DONNOGHUE, J. M.; TAYLOR, D. N.; BOSLEGO, J.; GARCIA MORENO, J.; HOPKINS, R. J.; DETOLLA, L. J. \& MORRIS, J. G., 1993. Serologic response to Helicobacter pylori among children and teenagers in northern Chile. American Journal of Tropical Medicineand Hygiene, 49:189-191.

SCHAUER, D. B.; HANDWERKER, J.; CORREA, P. \& FOX, J. G.; 1995. Detection of Helicobacter pylori in drinking water using polymerase chain reaction amplification. Gut, 37:27.
SIERRA, R.; MUÑOZ, N.; PEÑA, A. S.; BIEMOND, I.; VAN DUIJN, W.; LAMERS, C. B. H. W.; TEUCHMANN, S.; HERNANDEZ, S. \& CORREA, P., 1992. Antibodies to Helicobacter pylori and pepsinogen levels in children from Costa Rica: comparison of two areas with different risks for stomach cancer. Cancer Epidemiology, Biomarkers and Prevention, 1:449-454.

SITAS, F.; FORM AN, D.; YARNELL, J. W.; BURR, M. L.; ELWOOD, P. C.; PEDLEY, S. \& MARKS, K. J., 1991. Helicobacter pylori infection rates in relation to age and social class in a population of Welsh men. Gut, 32:25-28.

SM OAK, B. L.; KELLEY, P. W. \& TAYLOR, D. N., 1994. Seroprevalence of Helicobacter pylori infections in a cohort of US army recruits. American Journal of Epidemiology, 139:513-519.

SURVEYOR, I.; GOODWIN, C. S.; MULLAN, B. P.; GEELHOED, E.; WARREN, J. R.; MURRAY, R. N.; WATERS, T. E. \& SANDERSON, C. R., 1989. The 14C-urea breath test for the detection of gastric Campylobacter pylori infection. Medical Journal of Australia, 151:435-439.

VANDENPLAS, Y.; BLECKER, U .; DEVREKER, T.; KEPPENS, E.; NIJS, J.; CADRANEL, S.; PIPELEERSMARICHAL, M.; GOOSSENS, A. \& LAUWERS, S., 1992. Contribution of the 13C-urea breath test to the detection of Helicobacter pylori gastritis in children. Pediatrics, 90:608-611.

VEENENDAAL, R. A.; PEÑA, A. S.; MEIJER, J. L.; ENDTZ, H. P.; VAN DER EST, M. M.; VAN DUIJN, W.; EULDERINK, F.; KREUNING, J. \& LAMERS, C. B., 1991. Long term serological surveillance after treatment of Helicobacter pylori infection. Gut, 32:1291-1294.

VELDHUYZEN VAN ZANTEN, S. J.; TYTGAT, K. M.; HOLLINGSWORTH, J.; JALALI, S.; RSHID, F. A.; BOWEN, B. M.; GOLDIE, J.; GOODACRE, R. L.; RIDDELL, R. H. \& HUNT, R. H.; 1990. 14C-urea breath test for the detection of Helicobacter pyIori. American Journal of Gastroenterology, 85: 399-403.

WOTHERSPOON, A. C.; DOGLIONI, C.; DISS, T. C.; PAN, L.; MOSCHINI, A.; DE BONI, M. \&ISAACSON, P. G., 1993. Regression of primary low-grade B-cell gastric lymphoma of mucosa-associated Iymphoid tissue type after eradication of Helicobacter pylori. Lancet, 342:575-577. 